\title{
„Zařadit dnešní problémy do dlouhodobých souvislostí“, rozhovor o historické sociologii s Jóhannem Pállem Árnasonem
}

\author{
VEDLI BOHUSLAV Šalanda A JiŘí ŠUBRT
}

\section{Seeing Today's Problems in a Long-term Context, the Interview about Historical Sociology with Jóhann Páll Árnason}

Co Vás, pane profesore, nasměrovalo $k$ tomu, že jste se začal zabývat historickou sociologií? Měla na to nějaký vliv i ta skutečnost, že jste před řadou let studoval v Praze?

Zaměření na historickou sociologii bylo tak trochu předurčeno studiem: v Praze jsem studoval filosofii a historii, v Německu pak filosofii a sociologii. Sociologie byla na československých univerzitách rehabilitována až během mého pobytu v Praze, ale o přesedlání jsem neuvažoval. Na filosofickou problematiku navazuje svým vlastním způsobem ta větev historické sociologie, která mě nejvíce zajímá, tzn. srovnávací civilizační analýza, která se nedá dělat bez značné dávky filosofické antropologie. To platí o všech významných civilizacionistech, i když ne vždycky ve stejném smyslu. Můj zájem o historickou sociologii souvisí svým způsobem i se studiem v Praze: česká - a v širším smyslu československá - zkušenost ve dvacátém století je zvláště markantní ilustrací toho, že struktura a dynamika společností mohou být rozhodujícím způsobem ovlivněny historickými konstelacemi a proměnami, v neposlední řadě takovými, které se nedají žádným způsobem redukovat na obecné společenské trendy či vývojové linie. Sociologické bádání, které tuto fundamentální skutečnost nebere plně na vědomí, tím omezuje své perspektivy.

Čim pro Vás historická sociologie je? Jak byste charakterizoval předmět jejího bádání? $V$ čem podle Vašeho názoru spočívá její hlavni poslání?

Historická sociologie je pro mne především korektura dlouhodobého trendu vzájemného odcizování dvou oborů, historie a sociologie (Norbert Elias mluvil o „ústupu sociologů do př́tomnosti“) a návratem - na základě mezitím získaných poznatků - k propojení historických a sociologických perspektiv, které bylo charakteristické pro klasickou sociologii. Pokud takto chápeme dnešní situaci, půjde spíše o to rozšřrít předmět bádání historické sociologie, než ho předem vymezit. Mezi západními historickými sociology existuje, jak bylo vícekrát konstatováno, výrazný rozdíl mezi těmi, kterým jde o legitimaci nového dílčího oboru, a těmi, kteří chápou vzestup historické sociologie jako výzvu a př́ležitost k celkové reorientaci sociologie. Ztotožňuji se s druhým stanoviskem, které snad nejvýrazněji hájil Craig Calhoun. Tím je také v zásadě zodpovězena otázka po „hlavním poslání“: jedná se o důslednou „historizaci“ předmětů a kategorií společenských věd. Pro mne je pak zvlášt důležité, aby se historická sociologie zabývala civilizační dimenzí dějin, která se bez takového přístupu snadno stává předmětem metahistorických spekulací (jako u Spenglera nebo Toynbeeho).

Jak hodnotíte procesy historizace sociologie a sociologizace historie?

Podle mého názoru je legitimní mluvit o historizaci sociologie a sociologizaci historie. Oba procesy můžeme definovat tak široce, že nespadají vjedno s historickou 
sociologii ve striktnějším slova smyslu. O jistou, a bezpochyby velmi přínosnou, sociologizaci historie šlo např́klad u německé školy, označené od 70. let jako Sozialgeschichte a spojené se jmény, jako jsou Hans-Ulrich Wehler, Jürgen Kocka, Jürgen Osterhammel a Hartmut Kaelble. Zdá se dokonce, že úspěch této školy v Německu vzbudil u mnoha lidí dojem, že další sblížení oborů pod heslem historické sociologie už není zapotřebí. Kapitolami pro sebe jsou pak např́klad sociologické prvky vnesené jednak do dějin starověku, jednak do dějin středověku. Tak Moses Finley a Jacques Le Goff patřili na těchto dvou polích k průkopníkům, ale za historické sociology bychom je neoznačili. Na druhé straně si myslím, že klasická teorie modernizace se snažila o svého druhu historizaci sociologie, i když tento program definovala tak jednostranně, že při konfrontaci s konkrétní historií vznikly nepřekonatelné potíže. Konečné výsledky je asi nejlépe vidět ve dvou pozdních pracích Talcotta Parsonse: Societies- Evolutionary and Comparative Perspectives a The System of Modern Societies. V těchto dvou svazcích se vlastně podává sociologický výklad světových dějin. Důležité jsou dodnes také proto, že velmi dobře ilustrují přístup, proti kterému koncipoval Eisenstadt svou civilizacionisticky orientovanou historickou sociologii. Parsonsovy konstrukce bychom však dnes asi za historickou sociologii neoznačili; na to je historie příliš přímočaře podřízena schématům sociologické teorie. Dnešní program historické sociologie můžeme definovat jako další stupeň, tj. pokus o systematičtější vzájemnou integraci historických a sociologických pohledů - se silnější teoretickou náplní, než je tomu u Sozialgeschichte a větší historickou senzibilitou než v př́padě sociologie parsonsovského stylu.

Někdo může namítnout: $k$ čemu je vi̊bec studium historické sociologie. Jaké jsou přednosti kombinace sociologického a historického pohledu? Ostatně studium megatrendi̊ je $v$ př́tomné době dosti atraktivní.

Nejzákladnější přednost, přesněji naprostá nezbytnost kombinovaného historicko-sociologického pohledu spočívá v tom, že jedině tak můžeme adekvátně pochopit skutečnost, která je stejnou měrou - a nerozlučně - historická a společenská. Dají se ovšem uvést i specifičtější přednosti. Historicko-sociologické perspektivy nám umožňují zařadit dnešní problémy do dlouhodobých souvislostí a uplatnit přitom komparativní hlediska. To se mi zdá zvlášt důležité dnes, když se množí indicie toho, že máme co dělat s krizí západní modernity, zpychlé a otupělé „vítězstvím“ nad protivníkem, který se ve skutečnosti zhroutil sám pod tíhou svých vlastních nezvládnutelných problémů a nepromyšlených řešení. K tomu ještě konkrétní návrh: srovnání moderních krizí - a perspektiv vlastního zániku - s pozdní antikou má v evropském myšlení už dlouhou tradici. Bylo by dnes zajímavé zkoumat, v jakých kontextech se tato analogie objevuje a jak se její obsah proměňuje, ale i do jaké míry ve světle dnešních vědomostí a aktuální zkušenosti obstojí. Rozhodně bych však nechtěl tvrdit, že takové úvahy nebo historicko-sociologická reflexe vůbec nám dovolují předpovídat dějiny. Nejvýstřednější verze civilizacionistiky, jak ji najdeme např́k lad u Oswalda Spenglera, si takové cíle kladla, ale v dnešní diskusi se už nevyskytují. Studium megatrendů může být užitečné, ale dnes se to spíše přehání, a ve vztahu k budoucnosti nemůže vyústit v nic většího než extrapolaci, a to s veškerou nejistotou, která k takovým pokusům patří. 
Jedním ze zakladatelů historické sociologie je německý sociolog Max Weber, autor slavného pojednání o vlivu protestantismu na vznik moderní, kapitalistické společnosti. Jak Vy sám dnes hodnotíte Weberův odkaz? Co z něj považujete za aktuální a co za překonané?

Max Weber je pro mne nejen jedním ze zakladatelů historické sociologie, nýbrž i jejím nejživějším klasikem. Jeho odkaz je v mnoha ohledech svrchovaně aktuální a doposud nebyl dostatečně integrován do sociologického diskursu. Zdůraznil bych především pět aspektů. Na nejzákladnější úrovni se u Webera najde filosoficko-antropologická koncepce vztahů člověka a světa, soustředěná na pojem kultury jako osmyslnění světa (nejvýrazněji je formulována v jeho raném eseji o objektivitě společensko-vědního poznání), o kterou se může opřít srovnávací analýza historických a civilizačních formací jako různých způsobů ztvárnění světa. Za druhé tento důraz na jistý primát kultury nevedl ke kulturnímu determinismu à la Parsons. Weber v zásadě, i když ne vždycky v badatelské praxi, chápe společensko-historickou skutečnost jako proměnlivou skladbu kulturních, politických a ekonomických faktorů. Za třetí Weber spojil základní sociologické a historické problémy se srovnávací analýzou velkých civilizačních komplexů, a načrtl tím badatelský program, na který je - nehledě k nerovnoměrnému vývoji a jednostranným akcentům u Webera samotného - ještě možno navazovat. Za čtvrté Weber formuloval v tomto kontextu otázku specifičnosti a mimořádnosti evropského vývoje, a to způsobem, který se nedá označit za a priori eurocentrický, jak tvrdí postkoloniální kritikové (kteří Webera zřejmě většinou nečetli); ve své nejklíčovější formulaci (v úvodu k sebraným statím o sociologii náboženství) mluví totiž o „souhře okolností“ (Verkettung von Umständen), a nikoliv o esenciálních schopnostech či dispozicích, na jejichž základě by se evropský „Sonderweg“ dal vysvětlit jako metahistorická nutnost. Otázka evropské trajektorie - přesněji evropské cesty k modernitě - se týká empirických a kontingentních procesů, a tím pádem i vztahů $\mathrm{k}$ jiným civilizacím v různých historických fázích. A za páté si myslím, že Weber nejlépe ze všech klasiků pochopil multipolárnost a rozporuplnost modernity, a to je v dnešních debatách doposud zanedbané téma. Za překonané se pak dají považovat především ty aspekty Weberova díla, které zaostávají za jeho nejzásadnějšími perspektivami a nejpronikavějšími interpretacemi. Je například nutno říci, že zmíněná koncepce kultury není důsledně uplatněna v civilizačních studiích. Také je pravda, že př́íliš exkluzivní soustředění na vztahy mezi náboženskými orientacemi a hospodářským životem zastiňuje komplexnější souvislosti. Dvojnásob překonané jsou však pozdější konstrukce, které Weberovu problematiku ochuzují a podřizují redukcionistickým koncepcím společenských věd. To se vztahuje v prvé řadě na interpretace, které z Weberova „metodologického individualismu“ dělají axiomatický předpoklad, a tím znevažují kulturologickohermeneutický aspekt jeho díla. Tady je po mém soudu třeba připomenout, že u Webera - jako u mnoha jiných průkopnických badatelů - není metodologická reflexe vždycky na úrovni, která by zcela odpovídala jeho vlastním obsahovým poznatkům.

Významnou osobností historické sociologie 20. století je bezpochyby Norbert Elias. Měl jste možnost Eliase osobně poznat? V čem spatřujete silné stránky Eliasovy civilizační teorie $a v$ čem vidíte př́padně její slabiny?

Eliase jsem osobně poznal na konferenci o jeho díle v Bielefeldu v roce 1984, a později jsem se s ním ještě párkrát setkal. Byla to fascinující osobnost, aktivní badatel i ve vysokém věku a velmi zajímavý diskusní partner. Budiž v této souvislosti řečeno, 
že soudě podle mé zkušenosti nebyl tak uzavřený do vlastního konceptu a nepřístupný jiným pohledům, jak se někdy tvrdilo. Co se silných a slabých stránek jeho díla týče, dají se nejlépe vystihnout na př́kladě jeho dnes uznávaného klasického díla o civilizačním procesu. Jeho hlavní přínos tkví v tom, že poprvé rozvinul koncepci formování státu jako dlouhodobého procesu s rozsáhlými celospolečenskými důsledky a na specifičtější úrovni jako osové komponenty evropských dějin od raného středověku až do moderní doby. Slabiny pak souvisejí s přiliš redukcionistickým pojmovým rámcem a příliš exkluzivním soustředěním na evropskou vývojovou linii. Při formování státu jde o širší spektrum mocenských faktorů, než by se mohlo podle Eliasova výkladu zdát, a kulturní, respektive ideologická dimenze je u něho nesporně zanedbána. Komparativní perspektivy by v mnoha ohledech pomohly k lepšímu pochopení klíčových aspektů evropského vývoje. V neposlední řadě je pak, když se Elias vyjadřuje k obecným sociologickým otázkám, u něho patrný silný sklon k redukci sociální reality na mocenské vztahy a útvary.

Které soudobé badatele považujete za vi̊dčí osobnosti historické sociologie a v čem spatrujete jejich hlavni př́nos? Kteři historičtí sociologové jsou Vám názorově nejbliže?

Historická sociologie je dnes velmi produktivní a rozvětvený obor a dala by se vyjmenovat dlouhá řada významných představitelů. Omezím se na menší počet. Za nejvlivnějšího žijícího historického sociologa můžeme asi považovat Immanuela Wallersteina: založil mezinárodně vlivnou školu, která operuje s konceptem světového systému, i když ho někteří autoři této provenience oproti Wallersteinovým původním představám značně modifikovali. Wallersteinovo dílo je velmi podnětné i pro ty, kteří mají k jeho teoretickému modelu zásadní výhrady. Ty ostatně mám i já. K nejvýznamnějším osobnostem oboru nesporně patř̌́ Shmuel N. Eisenstadt, který je mi názorově nejbližší a který se nejvíce zasloužil o renesanci civilizacionistiky v posledních dekádách dvacátého století. Za velmi významného autora považuji také Michaela Manna, i když jde pro mne nepřijatelně daleko v redukci historicko-společenských formací na mocenské struktury. A nakonec je třeba jmenovat nedávno zesnulého Charlese Tillyho, jehož práce měly právem velký ohlas, i když je u něho výtka redukcionismu na místě stejně jako u Manna.

Jedním z klíčových pojmů Vaši historické sociologie je, pane profesore, civilizace. To je pojem, který bývá chápán a definován různými způsoby. Jakému pojetí dáváte přednost Vy sám? A jaké př́stupy naopak odmítáte?

V historii společenských věd se vyskytlo a dodnes existuje vícero pojmů civilizace a neexistuje koncepce nebo program civilizační analýzy, které by všechny tyto významové odstíny integrovaly. Zvlášt důležitý se mi zdá rozdíl mezi civilizací v singuláru a civilizacemi v plurálu. Pojem civilizace v singuláru v klasické sociologii - tj. především u Marxe a Durkheima, styčné body má však i notoricky mnohoznačná koncepce racionalizace u Maxe Webera - se vztahuje na rozvoj lidských schopností, lidského bohatství a lidských vztahů k světu a k sobě navzájem. Eliasova teorie civilizačního procesu operuje se singulárem, ale soustředuje se na proměny mocenských struktur a především na formy státnosti. Další pojetí civilizace v singuláru je ve hře, když se mluví o „počátcích civilizace“, a myslí se tím vznik kulturních útvarů, pro které jsou charakteristické tři inovace: elementární státní struktury, městská centra a písmo. Všechny tyto problémové okruhy by se měly důsledněji integrovat do pluralisticky pojaté civilizační ana- 
lýzy. Souhlasím ovšem s Eisenstadtem v tom, že nejzákladnějším výchozím bodem by měla být myšlenka nebo spíš fenomén civilizační plurality; definoval bych však takto pojaté civilizační útvary s větším důrazem na jejich mnohorozměrnost, kterou můžeme v první instanci pochopit jako skladbu kulturních, politických a ekonomických faktorů. Civilizační analýza uznává primát kultury v tom smyslu, že kulturní artikulace světa, se kterou jsou spojeny i kulturní definice politických a ekonomických sfér společenského života, tvoří klíč k pochopení širších civilizačních souvislostí. To by však nemělo vést ke kulturnímu determinismu; k takovému nedorozumění může vést Eisenstadtův pojem „kulturního programu“, který se vyjímá tak trochu jako přežitek z jeho parsonsovské fáze. Mluvil bych raději o kulturní problematice, abych zdưraznil, že jde o něco mnohoznačnějšího a méně jednostranně určujícího, než je program.

Dvě z Vašich knih se zabývají japonskou historií a civilizací. Co Vás přivedlo k tomu, že jste se začal zabývat právě Japonskem, co je pro Vás na japonské historii přitažlivé?

Zájem o Japonsko začal tím, že jsem se za studijních let v Praze hodně stýkal s japonskými studenty a získal dojem, že se jedná o zemi s mimořádně svébytnou kulturou a historickou zkušeností. Systematicky jsem se však začal Japonskem zabývat až mnohem později: od poloviny 80. let v Austrálii. Hlavním podnětem bylo, že se mi japonská zkušenost zdála velmi důležitá pro rozvíjející se diskusi o různých zdrojích, cestách a podobách modernity. O koncepci „multiple modernities“ nebyla tenkrát ještě explicitně řeč, ale kritikové starší modernizační teorie už zdůrazňovali specifické vývojové linie, v neposlední řadě mimoevropské. Koncem 80. let jsem pak navázal kontakt s Eisenstadtem, který se Japonskem také zabýval, a tím přibyl další důvod: Eisenstadt sice opíral svou civilizační teorii především o historickou zkušenost „osových civilizací“, tj civilizací poznamenaných velkými světonázorovými převraty, které se udály v době kolem poloviny posledního tisíciletí př. n. 1. Svou daleko nejdůležitější civilizační studii však napsal o civilizaci „neosové“, za kterou pokládá Japonsko, a o její specifické formě modernity. Abych se s tímto paradoxem vyrovnal, napsal jsem vlastní interpretaci japonské trajektorie, která celou její problematiku vykládá způsobem podstatně historičtějším a méně kulturalistickým, než to dělá Eisenstadt.

Spolu s profesorem Shmuelem Eisenstadtem a dalšími badateli rozpracováváte v současné době koncepci osových civilizací a rozmanitých modernit - Multiple Modernities. V čem spatřujete hlavní význam a př́nos tohoto bádání?

Eisenstadtovy práce se už delší dobu zaměřují především na dva jmenované tematické okruhy; spojené jsou jednak geneticky, tj. tím, že kulturní inovace osové doby (volně definované: jde o několik století kolem poloviny posledního tisíciletí př. n. 1.) se chápou jako historické kořeny moderních transformací, jednak z hlediska komparativního: k pochopení modernity je třeba srovnání s jinými historickými příklady radikálních změn, mezi kterými vyniká právě osová doba. Tyto dvě tematiky nebyly však zcela stejnoměrně integrovány do další diskuse. Co se osové doby týče, točí se debata v prvé řadě kolem otázky jednoty nebo plurality, která je u Eisenstadta jasně formulována, i když trochu jednostranně zodpovězena ve prospěch jednoty. $V$ př́padě modernity se klade větší důraz na rozmanitost cest, forem a problematik a méně se přihlíží k tomu, že Eisenstadtovy teze o „multiple modernities“ se opírají o jeho koncepci modernity jako nové, 
specifické civilizace, jejíž jádro tvoří soubor nových vizí lidské autonomie. Jde tedy, jinými slovy řečeno, o nové pojetí jak modernity v singuláru, tak i jejích rozrůzněných forem. S přihlédnutím $\mathrm{k}$ této korektuře bych řekl, že význam a přínos obou zmíněných badatelských projektů spočívá především v tom, že otvírají nové cesty pro komparativní historickou sociologii. Diskuse o osové době a o jejích nástupnických tradicích se stává - i když trochu složitějším způsobem, než to Eisenstadt očekával - východiskem pro srovnávací analýzu velkých civilizací, založenou na multilineárním pojetí dějin a oproštěnou od eurocentrických předpokladů. Aspoň na principiální úrovni, na úrovni konkrétních analýz jde spíše o dlouhodobý úkol. Problematika rozmanitých modernit se mi pak zdá nejslibnějším pokusem o vyrovnaný rozbor jednoty a plurality moderních socio-kulturních formací. Právě tato tématika se ukázala nezvládnutelnou v rámci modernizační teorie staršího typu, která začala se silně nadsazenou a idealizující koncepcí jednotného vývoje a cílů modernity, ale narazila v badatelské praxi na velmi pestrou zkušenost, kterou nemohla do svého kategoriálního rámce vměstnat.

Historická sociologie a civilizacionistika má vedle sebe dalši více či méně konkurenční obory, jako jsou např́klad politická geografie nebo sociální antropologie. Někdy je opravdu obtižné jasně vymezit predmět studia. Politická geografie se věnuje teritoriálním státům, ale vedle toho přece jen existují dalši možnosti organizace prostoru. Dále můžeme pripomenout geopolitiku a klasickou ,heartlandtheory“ Halforda Mackindera, která rovněž pracuje se světovými osami.

O konkurenčních oborech bych nemluvil, spíše o překrývajících nebo doplňujících se projektech. Historická sociologie má výrazně interdisciplinární záběr, a tím pádem i styčné body s jinými trendy ve společenských či humanitních vědách. Na souborném názvu ted’ př́liš nezáleží. Např́lklad historická antropologie není vždycky koncipována tak, že by se měla omezit na oblast každodenního života. Při širší definici se stírají hranice s historickou sociologií. Sám chápu civilizacionistiku tak, že má silnou antropologickou složku. Tak to vidí rovněž Jaroslav Krejčí, i když jeho přístup je v mnohém jiný. Zmíněná geopolitická tradice je podle mého názoru důležitá pro historickou sociologii, v neposlední řadě i pro civilizacionistiku, a mělo by se udělat víc pro využití jejího potenciálu. Zatím se takové snahy vyskytují hlavně mezi historiky. Patří k nim například David Christian, jehož pohled na eurasijské dějiny je silně poznamenán geopolitickými perspektivami; totéž platí o různých novějších pracích k dějinám ruské i čínské říše.

Mezi zajímavá témata patři typologie impérií či říši ve světových dějinách. V tomto př́padě lze vhodně uplatnit komparativní i historické hledisko, jinak řečeno: hledisko historickosociologické a politologické. Fenoménu impérii zdařile věnoval pozornost např́klad politolog z Humboldtovy univerzity Herfried Münkler (Imperien. Die Logik der Weltherrschaft - von Alten Rom bis zu den Vereinigten Staaten). Opravdu můžeme ř́ci, že žijeme v době postimperiální?

Z hlediska civilizační analýzy je problematika impérií (hlavně těch, u kterých je možno mluvit o světových ř́ších) stěžejní a přitom málo zpracované téma; což je o to nápadnější, že Eisenstadtova cesta k civilizační analýze vedla přes široce pojatou komparativní studii o imperiích (The Political Systems of Empires). Po vypracování pojmového rámce pro srovnávací studium civilizací se však v podstatě k imperiím nevrátil (pouze na 
okraji diskuse o osových civilizacích) a nikdo jiný se zatím tohoto tématu neujal. Jedná se přitom o několik problémových okruhů. Za prvé nesou různé projekty, modely a tradice imperiálního panství pečet různých civilizací, přičemž je například markantní rozdíl mezi byzantskými, čínskými a islámskými tradicemi. Za druhé impéria často překračují civilizační hranice, a tvoří tím pádem historické konstelace a prostory zvláštního druhu. Za třetí jsou imperiální formace jedním z nejnázornějších příkladů autonomní dynamiky mocenských struktur, a proto by bližší studium pomohlo vyvážit tendence ke kulturnímu determinismu. A za čtvrté si myslím, že je třeba ještě diskutovat otázku, kterou nastolil Eisenstadt ve své knize o impériích: v jakém smyslu a do jaké míry se jedná u imperiálních formací o anticipaci nebo zárodečnou fázi modernizačních procesů. Jinými slovy se běží o specifické stírání hranic mezi tradičním a moderním světem. Těmto problémům se Münklerova kniha nevěnuje. Je to informativní a podnětná práce, ale z hlediska pojmové struktury nepř́liš zdařilá. Co se poslední otázky týče, rozhodně si nemyslím, že žijeme v postimperiální epoše. Podle mého názoru je namístě mluvit o americkém impériu a u možných rivalů Ameriky se také jedná nebo může jednat o imperiální ambice.

Život a dílo významného civilizacionisty Samuela Huntingtona se 24. 12. 2008 uzavřely. Jak bude vypadat sociální teorie po Huntingtonovi? Lze se nadále opř́t o jeho poslední teze, že hranice mezi kulturami nevede jen napřčc jednotlivými areály, nýbrž probíhá uvnitř národních států? Tak např. hromadné pristěhovalectví Hispánců do USA způsobuje, že v zemi nastává dvojjazyčnost, což predstavuje významný posun v dějinách dosavadni Ameriky.

Huntington byl složitý př́ípad. Jeho dílo je velmi rozsáhlé a nemělo by se ztotožňovat s pozdní civilizacionistickou fází. K cenným pracím patří například jeho kritika modernizační teorie z konce 60. a 70. let. Stálo by ostatně za bližší zkoumání, jak se vlastně dostal k civilizacionistice - myslím, že to ještě nikdo neudělal. Co se pak jeho známé knihy o střetu civilizací týče, je třeba nejdříve říci, že byla často nespravedlivě kritizována. Rozhodně není pravda, že by si byl civilizační konflikty přál, nebo že by si byl myslel, že žádná prevence není možná. Naopak kniha pojednává obšírně o tom, jak neutralizovat nebo zmírnit takové konflikty. Nesmyslné se mi zdá tvrzení, že Huntington nechtěl nic jiného než ideologicky zdůvodnit americkou zahraniční politiku, přičemž od ní zachoval větší distanci než mnozí jiní prominentní učenci. Hlavní slabinu jeho civilizacionistiky vidím však v tom, že se velmi málo staral jak o základní pojmosloví, tak i o pochopení odlišných přístupů historiků a sociologů, na které navázal. V dlouhé poznámce na konci své knihy cituje významné představitele civilizacionistiky, ale zdá se, že je hází všechny do jednoho pytle. Nedostatek teoretické průpravy se pak odráží ve vágních definicích, jako například ve tvrzení, že civilizace jsou „the ultimate tribes.“ Pokud jde o empirickou část jeho argumentace, myslím, že věcnější část kritiky, která mu byla adresována, ukázala, že se sice dá mluvit o civilizačních aspektech mezinárodních konfliktů, ale že civilizační faktory se proplétají s jinými mnohem složitějším způsobem, než si Huntington myslel. Někdy se také jedná o empirické „howlery“, z nichž nejhorší je snad teze, že Austrálie je Turecko naruby, tzn. západní země, která se chce stát asijskou. Celkem vzato se dá asi říci, že Huntington prokázal civilizacionistice dvojznačnou službu: popularizoval její problematiku, ale způsobem, který jí dvakrát neprospěl. 
Jaké jsou, pane profesore, Vaše pracovni plány pro nejbližši budoucnost? Jakým výzkumným otázkám byste se chtěl v následujicích letech věnovat?

$\mathrm{V}$ nejbližších letech bych se chtěl věnovat především civilizační analýze, a to na dvou úrovních. Jednak si myslím, že by se měl napsat systematičtější výklad stěžejních pojmů civilizační analýzy, než jsem zatím mohl předložit. Kapitola věnovaná tomuto tématu v knize Civilizations in Dispute, která byla napsána před sedmi lety, se mi ted’ jeví jako provizorní pokus, i když si nadále myslím, že trojice základních antropologickosociologických kategorií - smysl, moc a bohatství - tvoří páteř pojmové soustavy, o kterou půjde. Za druhé připravuji soubor esejů, které aplikují civilizační perspektivu na specifičtější teoretická a historická témata; měl by vyjít u nakladatelství Brill koncem roku 2010 s titulem Encounters and Interpretations: Essays in Civilizational Analysis. Na okraj bych se chtěl zmínit o tom, že s jedním německým kolegou chceme společně napsat knihu o národech a nacionalismu z civilizačního hlediska - myslíme si oba, že právě na tomto poli by civilizační přístup mohl přispět k vyjasnění sporných otázek.

Jóhann Páll Árnason (1940) emeritní profesor sociologie na La Trobe University v Melbourne, kromě toho působí na Fakultě humanitních studii Karlovy Univerzity v Praze. Zabývá se hlavně teoretickými a historickými otázkami srovnávací civilizační analýzy. Publikoval mimo jiné práci Civilizations in Dispute (2003).

Kontakt: Fakulta humanitních studii, U Kř́že 8, 15800 Praha 5 - Jinonice

E-mail: J.Arnason@latrobe.edu.au 